$11-22-2017$

\title{
Student attitudes toward group discussions
}

Virginia Clinton

University of North Dakota, virginia.clinton@und.edu

Alison E. Kelly

University of North Dakota, alison.e.kelly@und.edu

How does access to this work benefit you? Let us know!

Follow this and additional works at: https://commons.und.edu/efr-fac

Part of the Education Commons

\section{Recommended Citation}

Clinton, V. \& Kelly, A. (in-press). Student attitudes toward group discussions. Active Learning in Higher Education. DOI: $10.1177 / 1469787417740277$

This Article is brought to you for free and open access by the Department of Educational Foundations and Research at UND Scholarly Commons. It has been accepted for inclusion in Educational Foundations and Research Faculty Publications by an authorized administrator of UND Scholarly Commons. For more information, please contact und.commons@library.und.edu. 


\title{
Student attitudes towards group discussions
}

\author{
Virginia Clinton and Alison E. Kelly
}

Please cite as the following:

Clinton, V. \& Kelly, A. (in-press). Student attitudes toward group discussions. Active Learning in Higher Education. doi: 10.1177/1469787417740277

\section{Biographical/contact details of authors}

Virginia Clinton. University of North Dakota, 231 Centennial Dr., Grand Forks, ND, 58202, USA. Tel: (701) 777-5793. Email: virginia.clinton@und.edu

Alison E. Kelly. University of North Dakota. Email: alison.e.kelly@und.edu

Virginia Clinton is an Assistant Professor in Educational Foundations and Research at the University of North Dakota. She holds a masters' degree in Teaching English to Speakers of Other Languages from New York University and a doctorate in Educational Psychology from the University of Minnesota. Dr. Clinton's research focuses on affective factors in student cognition and learning.

Alison Kelly is an Assistant Professor in Psychology at the University of North Dakota. She holds a doctorate in Experimental Psychology from the University of North Dakota. Dr. Kelly's research focuses on how cognitive processes influence eyewitness memory and identification.

\begin{abstract}
Student attitudes toward active learning techniques, such as group discussion, are often negative. The purpose of this study is to determine if an intervention informing students of the usefulness of group discussions affects their attitudes on group discussions. Students were randomly assigned to view a video and answer an essay question on either the value of group discussions (treatment) or on how group discussions were graded (control). Students in the treatment indicated group discussions as more useful as students in the control. Importantly, there were no differences in attitudes prior to the intervention. In addition, students reported their perceptions of the value (benefits) and costs (disadvantages) of group discussions in open-ended items. Findings are informative for pedagogical practice as well as designing future interventions.
\end{abstract}

Keywords: active learning, group discussions, student attitudes, motivation

\section{Student attitudes toward group discussions}

Group discussions are valuable methods of engaging students with material and teaching interpersonal communication skills (Smith et al., 2009; see Prince, 2004 for a review). However, students are often resistant to collaborative learning methods such as group discussions, instead preferring to listen to lectures (Machemer and Crawford, 2007; Lobo, 2017). One suggestion to encourage positive student attitudes toward group discussions is to directly inform them of its benefits (Bailey et al., 2015; Bishop et al., 2014; Shimazoe and Aldrich, 2010). However, empirical data on the effectiveness of this approach are lacking. The purposes of this study are to examine the effectiveness of an intervention informing 
students of benefits of group discussion on student attitudes toward group discussions and to better understand student perceptions of the value and costs of group discussion.

Group discussions, in which small groups of students answer questions about course content, have been demonstrated to be an effective active learning technique to enhance student engagement and learning (Freeman et al., 2014; Gibbs, 2010; Johnson and Johnson, 2014). Findings indicate that collaborating with other students, such as through group discussion, promotes retention of course content better than lecture alone (Mohamed, 2008; Saville et al., 2005). Indeed, even when all of the students in a group do not initially know the answer to a question, the process of discussion appears to improve accuracy (Smith et al., 2009). The opportunity for students to explain course information to each other is considered the main reason group discussions promote understanding of the material (Race, 2009). In addition, interacting in groups has been found to facilitate the development of critical thinking skills when compared to lectures alone, specifically regarding the evaluation of new material (Fung and Howe, 2014). Group discussions may foster students' independent learning skills allowing them to be more autonomous in their education (Gibbs and Jenkins, 1992). Furthermore, group discussions strengthen collaborative skills (Sancho-Thomas et al., 2009), and college graduates frequently report that their education did not adequately develop these skills (Bailey et al., 2015). Indeed, the need to train students for the teamwork demands of the workforce encouraged the use of group work in postsecondary instruction (Elton, 1997).

Concerns about student resistance to active learning methods, such as group discussion, are common among faculty (Seidel and Tanner, 2013). Indeed, a substantial number of students have negative attitudes toward group work, including group discussions (Hillyard et al., 2010; Soetanto and MacDonald, 2017; Zschocke et al., 2016). These negative attitudes often stem from the perception that group discussions are not beneficial to their learning and that lectures are a more efficient use of class time (Race, 2014). In addition, students often are unsure of what the purposes of group discussions are (Hillyard et al., 2010). Moreover, students may have communication problems when working in groups that they do not experience when listening to lectures (Soetanto and MacDonald, 2017). For these reasons, it is not surprising that students may perceive group discussions as less important than lectures (Race, 2009).

Student attitudes toward group discussions are of critical importance--not surprisingly, students who had more positive attitudes toward collaborative learning performed better in a course that incorporated collaborative learning (Gorvine and Smith, 2015). This is likely because if students embrace active learning activities, such as group discussion, they are more likely to engage with the course (Cavanagh et al., 2016). One recommendation for improving student attitudes toward collaborative learning is to explain the rationale behind them (Bailey et al., 2015; Bishop et al., 2014; Shimazoe and Aldrich, 2010); however, there has not been direct empirical examination of the effectiveness of this recommendation (Seidel and Tanner, 2013).

A theoretical lens through which to guide approaches to improve student attitudes toward group discussions is the expectancy-value model of motivation. According to this theory, the perceived value of a task is a major component in determining motivation to engage in that task (Wigfield and Eccles, 2000). The value of a task comes primarily from utility and intrinsic value (Eccles and Wigfield, 2002). Utility value is the usefulness of the task or the relevance of the task to one's life (Hulleman et al., 2008). For example, one source of utility value for taking advanced coursework in high school is to prepare for college. In this way, someone who wants to do well in college will be more motivated to take advanced classes in high school as they will perceive completion of such coursework as useful and personally relevant. Distinct from utility value, intrinsic value stems from one's enjoyment of or inherent interest in a task (Eccles and Wigfield, 2002). For example, one source of intrinsic value for taking advanced coursework in high school would be an inherent enjoyment of the intellectual challenge and/or interest in the material in the courses.

An effective approach to improving students' attitudes toward their courses based on this theory has been through utility-value interventions (Lazowski and Hulleman, 2016). Interventions have focused on utility as opposed to intrinsic value, as utility value is considered to be more malleable by external factors than intrinsic value (Harackiewicz et al., 2012). Utility-value interventions may involve informing students about 
the benefits of engaging in a task. For example, one utility-value intervention to encourage enrollment in high school mathematics and science courses involved high school students reading interviews from current college students who explained how the high school mathematics and sciences courses they took helped them in their college coursework (Rozek et al., 2015). Another approach with utility-value interventions involves having students write about the personal relevance or applicability of the material to their life goals (Hulleman and Harackiewicz, 2009; Hulleman et al., 2010). These writing exercises are thought to improve attitudes toward the course through increasing the personal significance or importance of the course information (Hulleman et al., 2008). For example, a study of one utility-value intervention in which high school students wrote about the relevance of their science courses by connecting the content to their lives found that the writing assignments increased motivation to learn more about science (Hulleman and Harackiewicz, 2009).

Given the issues surrounding group discussions, there is a need to test an approach for improving student attitudes toward group discussions. Findings have indicated utility-value interventions are most effective when students receive direct communication on utility value and then generate their own thoughts (Canning and Harackiewicz, 2015). If this approach is effective, it would provide instructors with a simple and evidence-based approach to encourage students to "buy in," or see the value of, group discussions. The following research questions need to be explored.

1) Do pre-intervention differences in preferences for individual or group work and discomfort with group work exist between the students? In particular, do students exposed to the intervention (that is, learning about the benefits of group discussion) differ in their preference for individual or group work and their level of discomfort with group work compared to students not exposed to the intervention? This is examined in case the students who receive the intervention and those who do not differ in their attitudes beforehand.

2) Does exposing students to the benefits of group discussion influence their attitudes toward group work? Based on research (see Lazowski and Hulleman, 2016), it is predicted that students who receive a utility-value intervention would indicate higher levels of utility value. In addition, the utility-value intervention could lead to better engagement in group discussions, leading to greater intrinsic value compared to students who do not receive such an intervention (Hulleman et al., 2017). However, the effect of the intervention is expected to be greater for utility value than intrinsic value.

3) Do the perceived value and costs differ depending on whether students are exposed to the intervention and how do students generally perceive the value and costs of group discussions? It is anticipated that students who receive the intervention would incorporate ideas from the intervention in their perceptions in their open-ended responses. In addition, examining student perceptions of value and cost of group discussions allows for better understanding of the issue.

\section{Method}

\section{Context}

The study involved an undergraduate Social Psychology course with an enrollment of 75 students at a mid-sized, Midwestern public university. Eight group discussion opportunities were provided throughout the spring 2017 semester. Group discussions were structured as follows. On each discussion day, students formed groups of 3-4 students, with the group member makeup of their choosing. Groups discussed 2-3 questions that applied or extended material covered during class. To track participation and grades, groups assigned a member to record responses to turn in on each discussion day. Each group could earn up to 5 points for group discussion participation, with the number of points earned being contingent upon the quality (and accuracy) of the group's responses. Group discussion points counted toward $10 \%$ of students' final grade in the course. Prior to the beginning of the course, a proposal for this research, specifying the student data involved, was reviewed and approved by the institution's Internal Review Board.

\section{Participants}


All students enrolled in the course were eligible for participation. Of the 75 students enrolled in the course, 51 completed all the necessary measures (both of the questionnaires and the syllabus quiz) and reported that they did not see the video for the other condition. Of these 51 students, there were 44 women and 7 men who ranged in ages from 19 to $50(M=20.89$; $S D=4.22$ years $)$. Most of the students identified as Caucasian (92\%), with $4 \%$ identifying as African American and $4 \%$ identifying as Native American.

\section{Procedure}

Students were randomly assigned to either the treatment $(N=25)$ or the control $(N=26)$ condition. In the first week of the semester, students were invited to complete a questionnaire about their preferences for individual or group work (pre-intervention questionnaire) and received three bonus points as compensation. All students were required to view a video on group discussions and complete a quiz on the course Learning Management System. The video in the treatment condition presented evidence for the benefits of group discussions. The slides for the video are available upon request from the first author. Specifically, the treatment video explained that: 1) group discussions are beneficial for developing critical thinking (Fung et al., 2016), 2) group discussions are a type of active learning and active learning is beneficial for student academic performance (Freeman et al., 2014), and 3) group discussions develop skills desired by employers (Carnevale and Smith, 2013). In contrast, the video in the control group went over procedures and grading for group discussions.

After viewing the video, students were required to complete a quiz on the syllabus and the video. The 10 multiple-choice items regarding the syllabus were identical in the two conditions. However, the last item in the quiz was a short essay prompt that varied by condition. For the treatment condition, students received the prompt "Based on the video you saw on group discussions in this course, write 2 paragraphs on how group discussions may be useful for learning course material or relevant to your life goals. Give at least 2 examples." For the control condition, students received the prompt "Based on the video you saw on group discussions in this course, write 2 paragraphs on how group discussions will be structured and graded in the course." On the seventh week of the semester, students were asked to complete a post-intervention questionnaire on the value of group discussions and received three bonus points as compensation.

\section{Measures}

Prior to administering the questionnaires, the measures were reviewed for clarity by students who were not enrolled in the course for this study. The internal consistency of the items for each measure was examined by testing the interrelatedness of each item through Cronbach's alpha $(\alpha)$ with higher alpha levels indicating higher interrelatedness.

Pre-intervention questionnaire. In this questionnaire (adapted from Cantwell and Andrews, 2002), there were seven items that composed the scale for preference to work individually (Cronbach's $\alpha=.79$ ), seven items that composed the scale for preference to work in groups (Cronbach's $\alpha=.59$ ), and four items that composed the scale for discomfort with group work (Cronbach's $\alpha=.67$ ). For each of these items, participants were asked to indicate their level of frequency on a 1-6 Likert rating from Almost Never to Almost Always. Questions regarding demographics were included at the end of the questionnaire.

Post-intervention questionnaire. In this questionnaire, there were six items that composed the scale for intrinsic value (Cronbach's $\alpha=.89$ ) and six items for utility value (Cronbach's $\alpha=.88$; adapted from Hulleman and Harackiewicz, 2009). For each of these items, participants were asked to indicate their level of agreement on a 1-5 Likert rating from Strongly Disagree to Strongly Agree. There were also three open-ended items regarding the perceived intrinsic value ("What is the value of group discussion in class?"), utility value (How are group discussions useful for you, now or in the future?"), and cost of group discussions ("What are the costs or downsides of group discussions in class?).

To determine if there were a priori differences in preferences for group or individual work between the treatment and control conditions, three one-way analysis of variance tests were conducted with condition as the independent variable and with preference for individual work, preference for group work, and discomfort with group work as the dependent variables. To test the effects of the intervention (i.e., 
learning about the usefulness of group discussions) on attitudes toward group work, two one-way analysis of variance tests were conducted with condition as the independent variable and with intrinsic value of group discussions and utility value of group discussions as the dependent variables. The openended questionnaire items on value were dichotomously scored for mentioning ideas from the intervention video ( 1 for having an idea, 0 for not). Then, binary logistic regression with condition as the independent value was used to test if the condition influenced inclusion of ideas from the video. The open-ended items were also coded through a content analysis in an inductive manner based on themes in order to understand student perspectives on the value and cost of group discussions (see Barry, Murphy, and Drew, 2015, for a similar approach). The frequency of these codes was tallied for each item (note that some students provided more than one response so there are more tallies than students).

\section{Results}

1) Did pre-intervention differences in preferences for individual or group work and discomfort with group work exist between students?

There were no differences between the students who learned about the usefulness of group discussion and those who did not for preference for individual work, $F(1,50)=1.21, p=.28$, preference for group work, $F(1,50)=.46, p=.50$, or discomfort with group work $F(1,50)=.70, p=.42$. Students exposed to the intervention (that is, those who learned of the benefits of group discussion) did not differ in their preference for individual or group work or their discomfort with group work than students in the control (that is, those who learned about how group discussions were graded). See Table 1 for means and standard deviations by condition.

$<<$ Insert Table 1 here $>>$

2) Did exposing students to the benefits of group discussion influence their attitudes toward group work?

There was no effect of the intervention on intrinsic value of group discussions, $F(1,50)=.33, p=.57$. In other words, being made aware of the benefits of group discussion did not increase students' reported enjoyment or inherent interest in group discussions. However, the students in the intervention condition reported greater utility value of group discussions than did the students in the control condition, $F(1,50)=$ 5.21, $p=.03$, Cohen's $d=.62$. In other words, being made aware of the benefits of group discussion increased students' perceptions of the usefulness and relevance of group discussions. See Table 1 for means and standard deviations by condition.

3) Did the perceived value and costs differ depending on whether students were exposed to the intervention and how did students generally perceive the value and costs of group discussions?

There was no difference between conditions for either the intrinsic value, $\mathrm{B}=.45$, SE $=.58$, Wald $=.59$, $\operatorname{Exp}(\mathrm{B})=.86, p=.79$, or the utility value items, $\mathrm{B}=-.15, \mathrm{SE}=.57$, Wald $=.20, \operatorname{Exp}(\mathrm{B})=.80, p=.66$. Students who watched the video about the benefits of group discussion (treatment) did not mention ideas provided in the video more than students who watched the video about how group discussions were graded (control). See Table 1 for means and standard deviations by condition.

As can be seen in Table 2, students generally perceived the value of group discussions in terms of usefulness rather than inherent interest or enjoyment.

$<<$ Insert Table 2 here $>>$ 
The most frequently noted source of perceived value of group discussions for both conditions was improved understanding of course material followed by exposure to other viewpoints. In terms of utility value (the usefulness of group discussions; see Table 3), the opportunity to develop communication and teamwork skills was the most common response followed by the opportunity to interact with others or get other perspectives.

$\ll$ Insert Table 3 here $>>$

In terms of costs (see Table 4), the most common response was that group discussions take time as well as social loafing, unengaged, or unprepared peers.

$<<$ Insert Table 4 here $>>$

\section{Discussion and conclusion}

The purpose of this study was to test the effectiveness of an intervention informing students of benefits of group discussion on student attitudes toward group discussion. Based on the findings, the intervention was effective given that students in the treatment condition had higher ratings of the utility value (usefulness and relevance to one's life) of group discussions than did students in the control condition. However, there were no differences in intrinsic value (inherent interest or enjoyment) between the two groups of students. There did not appear to be differences between the students who did or did not learn about the usefulness of group discussions in terms of preferences for group or individual work prior to the intervention.

As previously discussed, group discussions are beneficial for learning (Saville et al., 2005; Smith et al., 2009), but students often dislike working with their peers (Hillyard et al., 2010; Soetanto and MacDonald, 2017). Informing students of the rationale for active learning techniques, such as group discussions, has been suggested as a method to address student resistance (Bailey et al., 2015; Bishop et al., 2014). To our knowledge, this study is the first empirical test of the effects of informing students of the utility of an active learning technique (in this case, group discussion) on attitudes towards that technique. Based on our findings, explaining the usefulness of an active learning technique to students appears to have a benefit on attitudes towards that technique, although the benefit may be limited to perceived usefulness and does not extend to intrinsic value (inherent interest in the task).

The findings from this study build on and align with other work based on the expectancy-value theory of motivation. In previous work, student attitudes towards their courses in general have been improved by emphasizing the usefulness or personal significance (that is, utility value interventions) of the course content. The study described in this article addressed attitudes toward an active learning technique (that is, group discussions) rather than attitudes towards the course content. However, unlike findings in some studies (Hulleman and Harackiewicz, 2009; Hulleman et al., 2010), the utility-value intervention did not increase intrinsic value in group discussions. In other words, the learning about the usefulness of group discussions appeared to help students appreciate the practical, useful benefits of group discussions, but did not appear to affect how much they enjoyed group discussions.

One possible reason the study findings did not indicate an effect on intrinsic value is that the intervention only involved one video and writing assignment whereas previous studies had multiple writing assignments (Hulleman and Harackiewicz, 2009; Hulleman et al., 2010). Another reason could be the utility-value intervention in this study was directed towards an active learning technique, not a content area as in previous studies (for example, Hulleman et al., 2017). It is possible that intrinsic enjoyment of active learning techniques may relate more to personal preferences and personality traits (see ChamorroPremuzic et al., 2007; Koper, 2015; McNally et al., 2017), than whether or not the technique is perceived as personally useful. 
Based on the responses to the open-ended items, incorporation of ideas from the intervention were similar in the two conditions. This may be because students are aware of the reasons why group discussions have value, but elaborating on the value in the intervention may have enhanced appreciation of group discussions as indicated by the quantitative utility value ratings. Another possibility is that students who received the intervention may have mentioned what they learned in the video to students in the control condition. In this way, most of the students in the class would have been aware of the reasons group discussions have value presented in the intervention video.

There are limitations to this study. In particular, this study examined the simple effects of an approach to improve student attitudes toward group discussion in one course, which was predominantly female. Additionally, students in the social psychology course were learning about group behavior and some may also have had prior knowledge of group behavior from other psychology courses, possibly influencing their responses. Further, students were allowed to choose their own groups, which is not the practice in every college classroom. The study was also carried out using only undergraduate students in one discipline from only one university and in only one particular country, limiting the generalizability of the findings. Clearly, the approach tested in this study needs to be adapted and tested in different environments before claims about its effectiveness can be made. Future studies could address this in different learning scenarios. One particular area that may be in need of examination is online discussions, given the rising popularity of online courses (Ortagus, 2017). Furthermore, the perceived costs of group discussions noted by students provide direction for future interventions. An intervention that directly addresses perceived costs of group discussions may be especially effective in improving student attitudes.

Informing students of the benefits of active learning techniques, such as group discussions, has been suggested as a method of improving student attitudes (Bailey et al., 2015; Bishop et al., 2014; Shimazoe and Aldrich, 2010). This study served to provide empirical support for this suggestion. In addition, this study informs our understanding of how students perceive the value and costs of group discussion for refinement of future interventions.

\section{Funding}

This research received no specific grant from any funding agency in the public, commercial, or not-forprofit sectors.

\section{References}

Bailey S, Barber LK and Ferguson AJ (2015) Promoting perceived benefits of group projects: The role of instructor contributions and intragroup processes. Teaching of Psychology 42(2): 1-5.

Barron KE and Hulleman CS (2015) Expectancy-Value-Cost model of motivation. In Wright, JD (ed.) International Encyclopedia of the Social and Behavioral Sciences, $2^{\text {nd }}$ edition. Oxford: Elsevier, $503-$ 509.

Barry S, Murphy K and Drew, S (2015) From deconstructive misalignment to constructive alignment: Exploring student uses of mobile technologies in university classrooms. Computers \& Education 81(2): 202-210.

Bishop CF, Caston MI and King CA (2014) Learner-centered environments: Creating effective strategies based on student attitudes and faculty reflection. Journal of the Scholarship of Teaching and Learning 14(3): 46-63.

Canning EA and Harackiewicz JM (2015) Teach it, don't preach it: The differential effects of directlycommunicated and self-generated utility value information. Motivation Science 1(1): 47-71.

Cantwell RH and Andrews B (2002) Cognitive and psychological factors underlying secondary school students' feelings towards group work. Educational Psychology 22(1): 75-91.

Carnevale AP and Smith, N (2013) Workplace basics: the skills employees need and employers want. Human Resource Development International 16(5): 491-501. 
Cavanagh AJ, Aragon OR, Chen $X$ et al (2016) Student buy-in to active learning in a college science course. CBE Life Science Education 15(4): 1-9.

Chamorro-Premuzic T, Furnham A and Lewis M (2007) Personality and approaches to learning predict preference for different teaching methods. Learning and Individual Differences 17(3): 241-250.

Eccles JS and Wigfield A (2002) Motivational beliefs, values, and goals. Annual Review of Psychology 53(1): 109-132.

Elton L (1997). University physics teaching in reduced circumstances. Physics Education 32(5): 346-350.

Freeman S, Eddy SL, McDonough M et al (2014) Active learning increases student performance in science, engineering, and mathematics. Proceedings of the National Academy of Sciences, USA 111: 8410-8414.

Fung CL and Howe CJ (2014) Group work and the learning of critical thinking in the Hong Kong secondary liberal studies curriculum. Cambridge Journal of Education 44(2): 245-270.

Fung DC, To H and Leung K (2016) The influence of collaborative group work on students' development of critical thinking: The teacher's role in facilitating group discussions. Pedagogies: An International Journal 11(2): 146-166.

Biggs $G$ and Jenkins A (1992) Conclusion: Improving teaching and learning in large classes. In Gibbs, B and Jenkins, A (Eds). Teaching Large Classes in Higher Education. How to Maintain Quality with

Reduced Resources. London: Kogan Page, 159-163.

Gibbs G (2010) The Assessment of Group Work: Lessons from the Literature. Assessment Standards

Knowledge Exchange (Centre for Excellence in Teaching and Learning in Higher Education, Oxford

Brookes University) Available at

http://www.york.ac.uk/media/staffhome/learningandteaching/documents/keyfactors/

The_assessment_of_group_work_lessons_from_the_literature.pdf (accessed May 2011).

Gorvine BJ and Smith HD (2015) Predicting student success in a psychological statistics course emphasizing collaborative learning. Teaching of Psychology 42(1): 56-59.

Harackiewicz JM, Canning EA, Tibbetts Y, Prinski, SJ and Hyde JS (2016) Closing achievement gaps with a utility-value intervention: Disentangling race and social class. Journal of Personality and Social Psychology 111(5): 745-765.

Harackiewicz JM, Rozek CS, Hulleman CS and Hyde JS (2012) Helping parents to motivate adolescents in mathematics and science: An experimental test of a utility-value intervention. Psychological Science 23(8): 899-906.

Hillyard C, Gillespie D and Littig P (2010) University students' attitudes about learning in small groups after frequent participation. Active Learning in Higher Education 11(1): 9-20.

Hulleman CS, Durik AM, Schweigert S and Harackiewicz JM (2008) Task values, achievement goals, and interest: An integrative analysis. Journal of Educational Psychology 100(2): 398-416.

Hulleman CS, Godes O, Hendricks BL and Harackiewicz JM (2010) Enhancing interest and performance with a utility value intervention. Journal of Educational Psychology 102(4): 880-895.

Hulleman CS and Harackiewicz JM (2009) Promoting interest and performance in high school science classes. Science 326(5958): 1410-1412.

Hulleman CS, Kosovich JJ, Barron KE and Daniel DB (2017) Making connections: Replicating and extending the utility value intervention in the classroom. Journal of Educational Psychology 109(3): 387404.

Johnson DW and Johnson RT (2014) Cooperative learning in $21^{\text {st }}$ century. Anales de Psicologia 30(3): 841-851.

Koper R (2015) How do students want to learn in online distance education? Profiling student preferences. International Review of Research in Open and Distributed Learning 16(1): 307-329.

Lazowski RA and Hulleman CS (2016) Motivation interventions in education: A meta-analytic review. Review of Educational Research 86(2): 602-640.

Lobo JG (2017) Active learning interventions and student perceptions. Journal of Applied Research in Higher Education 9(3): 465-473.

Machemer PL and Crawford P (2007) Student perceptions of active learning in a large cross-disciplinary classroom. Active Learning in Higher Education 8(1): 9-30.

McNally B, Chipperfield J, Dorsett P, et al. (2017) Flipped classroom experiences: student preferences and flip strategy in a higher education context. Higher Education 73(2): 281-298.

Mohamed AR (2008) Effects of active learning variants on student performance and learning perceptions. International Journal for the Scholarship of Teaching and Learning 2(2): Article 11. 
Ortagus JC (2017) From the periphery to prominence: An examination of the changing profile of online students in American higher education. The Internet and Higher Education 32(1): 47-57.

Prince M (2004) Does active learning work? A review of the research. Journal of Engineering Education 93(3): 223-231.

Race P (2009) In at the Deep End - Starting to Teach in Higher Education. Leeds: Leeds Metropolitan University.

Race P (2014) The Lecturer's Toolkit: A Practical Guide to Assessment, Learning, and Teaching. New York: Routledge.

Rozek, CS, Hyde, JS, Svoboda, RC, Hulleman, CS and Harackiewicz, JM (2015). Gender differences in the effects of a utility-value intervention to help parents motivate adolescents in mathematics and science. Journal of Educational Psychology 107(1): 195-206.

Sancho-Thomas P, Fuentes-Fernandez R and Fernandez-Manjon B (2009) Learning teamwork skills in university programming courses. Computers \& Education 53(2): 517-531.

Saville BK, Zinn TE and Elliot MP (2005) Interteaching vs. traditional methods of instruction: A preliminary analysis. Teaching of Psychology 32(3): 161-163.

Seidel SB and Tanner, KD (2013) "What if students revolt?" - Considering student resistance: Origins, options, and opportunities for investigation. CBE-Life Sciences Education 12(4): 586-595.

Shimazoe J and Aldrich H (2010) Group work can be gratifying: Understanding and overcoming resistance to cooperative learning. College Teaching 58(2): 52-57.

Smith MK, Wood WB, Adams WK et al (2009) Why peer discussion improves student performance on inclass concept questions. Science 323(5910): 122-124.

Soetanto D and MacDonald M (2017) Group work and the change of obstacles over time: The influence of learning style and group composition. Active Learning in Higher Education 18(2): 99-113.

Wigfield A and Eccles JS (2000) Expectancy-value theory of achievement motivation. Contemporary Educational Psychology 25(1): 68-81.

Zschocke K, Wosnitaza M and Bürger K (2016) Emotions in group work: insights from an appraisaloriented perspective. European Journal of Psychology in Education 31(3): 359-384. 
Table 1

Means and standard deviations of quantitative measures by condition

\begin{tabular}{llll}
\hline & $\begin{array}{l}\text { Treatment } \\
\mathrm{M}(\mathrm{SD}) \\
\mathrm{N}=25\end{array}$ & $\begin{array}{l}\text { Control } \\
\mathrm{M}(\mathrm{SD}) \\
\mathrm{N}=26\end{array}$ & $\begin{array}{l}\text { Total } \\
\mathrm{M}(\mathrm{SD}) \\
\mathrm{N}=51\end{array}$ \\
\hline Pre-intervention measures & & & \\
\hline Preference for individual work & $2.50(.74)$ & $2.71(.66)$ & $2.61(.71)$ \\
\hline Preference for group work & $3.41(.54)$ & $3.31(.55)$ & $3.36(.54)$ \\
\hline Discomfort with group work & $3.10(.85)$ & $2.89(.94)$ & $3.00(.90)$ \\
\hline Post-intervention measures & & & \\
\hline$\quad$ Intrinsic value of group discussions & $3.60(.73)$ & $3.47(.90)$ & $3.53(.82)$ \\
\hline Utility value of group discussions & $3.86(.77)$ & $3.33(.87)$ & $3.59(.86)$ \\
\hline $\begin{array}{l}\text { Ideas from intervention incorporated } \\
\text { (value) }\end{array}$ & $.64(.49)$ & $.54(.51)$ & $.59(.50)$ \\
\hline $\begin{array}{l}\text { Ideas from intervention incorporated } \\
\text { (usefulness) }\end{array}$ & $.52(.51)$ & $.54(.51)$ & $.53(.50)$ \\
\hline
\end{tabular}

Table 2

Examples and frequency of themes by condition for responses to the value of group discussion

\begin{tabular}{|c|c|c|c|c|}
\hline & Example & Treatment & Control & Total \\
\hline $\begin{array}{l}\text { Better/more in-depth } \\
\text { understanding }\end{array}$ & $\begin{array}{l}\text { "Group discussions help me, personally, to } \\
\text { better understand the material being } \\
\text { assessed within the lecture." }\end{array}$ & 12 & 10 & 22 \\
\hline Apply learning & $\begin{array}{l}\text { "To help students apply the course content to } \\
\text { real life situations." }\end{array}$ & 1 & 7 & 8 \\
\hline $\begin{array}{l}\text { Exposure to other } \\
\text { perspectives }\end{array}$ & "It allows me to see others' point of view" & 8 & 8 & 16 \\
\hline $\begin{array}{l}\text { Teaching/learning } \\
\text { from others }\end{array}$ & "Learn from peers" & 2 & 2 & 4 \\
\hline Teamwork skills & $\begin{array}{l}\text { "Everyone contributes and we work on our } \\
\text { teamwork skills." }\end{array}$ & 4 & 2 & 6 \\
\hline Career skills & $\begin{array}{l}\text { "It helps you acquire skills necessary for } \\
\text { future careers." }\end{array}$ & 1 & 1 & 2 \\
\hline Critical thinking skills & "Critical thinking" & 0 & 1 & 1 \\
\hline Helpful for shy people & $\begin{array}{l}\text { "I think that group discussions are useful for } \\
\text { those individuals who may not fully } \\
\text { understand the material, but are too } \\
\text { embarrassed or shy to ask for clarification out } \\
\text { loud in class." }\end{array}$ & 0 & 1 & 1 \\
\hline None/no answer & & 2 & 0 & 2 \\
\hline
\end{tabular}


Table 3

Examples and frequency of themes by condition for responses to the usefulness of group discussion

\begin{tabular}{|c|c|c|c|c|}
\hline & Example & Treatment & Control & Total \\
\hline $\begin{array}{l}\text { Better/more in-depth } \\
\text { understanding }\end{array}$ & $\begin{array}{l}\text { "Group discussions help me, } \\
\text { personally, to better understand the } \\
\text { material being assessed within the } \\
\text { lecture." }\end{array}$ & 2 & 7 & 9 \\
\hline Apply learning & $\begin{array}{l}\text { "I am able to apply what I am } \\
\text { learning." }\end{array}$ & 2 & 1 & 3 \\
\hline Career skills & $\begin{array}{l}\text { "My profession will include a lot of } \\
\text { group discussions, so having group } \\
\text { discussions in classes helps me } \\
\text { prepare for that part of my life in the } \\
\text { future" }\end{array}$ & 9 & 5 & 14 \\
\hline $\begin{array}{l}\text { Communication/teamwork } \\
\text { skills }\end{array}$ & $\begin{array}{l}\text { "Group discussions help me develop } \\
\text { my communication skills and help me } \\
\text { to better explain or express my ideas } \\
\text { to other people." }\end{array}$ & 8 & 11 & 19 \\
\hline $\begin{array}{l}\text { Interact with others/exposure } \\
\text { to other perspectives }\end{array}$ & $\begin{array}{l}\text { "It allows you to see new ideas or } \\
\text { ways of thinking." }\end{array}$ & 6 & 11 & 17 \\
\hline None/no answer & & 2 & 0 & 2 \\
\hline
\end{tabular}

Table 4

Examples and frequency of themes by condition for responses to the cost of group discussion

\begin{tabular}{|c|c|c|c|c|}
\hline & Example & Treatment & Control & Total \\
\hline $\begin{array}{l}\text { Social loafing/unengaged/ } \\
\text { Unknowledgeable peers }\end{array}$ & $\begin{array}{l}\text { "If people aren't willing to discuss, they } \\
\text { are useless." }\end{array}$ & 4 & 9 & 13 \\
\hline Time consuming & $\begin{array}{l}\text { "Time spent on group discussions may } \\
\text { take away from time to learn new } \\
\text { material." }\end{array}$ & 10 & 6 & 16 \\
\hline Off topic/socializing & $\begin{array}{l}\text { "I think group discussions can veer off- } \\
\text { topic, and lead to being unproductive." }\end{array}$ & 7 & 6 & 13 \\
\hline $\begin{array}{l}\text { Disagreements and difficult } \\
\text { personalities }\end{array}$ & $\begin{array}{l}\text { "People can disagree and not handle } \\
\text { the disagreements well." }\end{array}$ & 5 & 5 & 10 \\
\hline Confusion about task & $\begin{array}{l}\text { "I There may be some uncertainties, or } \\
\text { confusion between members of the } \\
\text { group." }\end{array}$ & 2 & 1 & 3 \\
\hline Dislike of talking with peers & $\begin{array}{l}\text { "Talking to people that you don't really } \\
\text { want to talk to, especially if you're shy, } \\
\text { can be hard." }\end{array}$ & 2 & 5 & 7 \\
\hline None/no answer & & 1 & 2 & 3 \\
\hline
\end{tabular}

